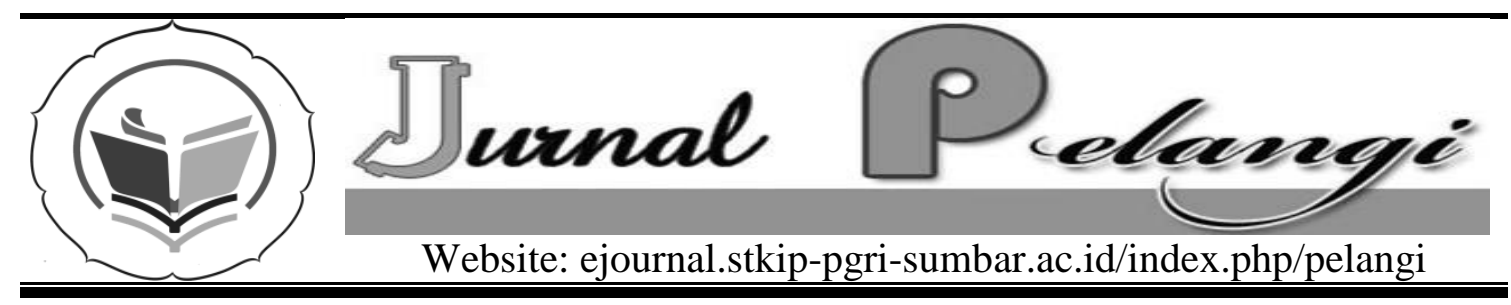

\title{
PENINGKATAN HASIL BELAJAR MATERI OPERASI HITUNG BILANGAN DENGAN PEMBELAJARAN KOOPERATIF TIPE MAKE A MATCH
}

\author{
Yurmayeti \\ SD Negeri 12 Kampung Melayu Agam \\ yurmayeti@yahoo.co.id
}

\section{INFO ARTIKEL}

\section{Diterima:}

1 Desember 2015

Direview:

9 Desember 2015

Disetujui:

22 Desember 2015

Kata Kunci:

Make a Match, Operasi Hitung Bilangan,

Hasil Belajar
Keywords:

Make a Match, Numbers Counting Operation,

Learning Outcomes

\begin{abstract}
Abstrak
Penelitian dilatar belakangi dari kenyataan di Sekolah Dasar bahwa pembelajaran sering didominasi oleh guru sebagai sumber informasi Berdasarkan pengamatan peneliti ditemukan hasil belajar siswa rendah. Disini peneliti menggunakan komponen-komponen rancangan pembelajaran Kooperatif Tipe Make a Match. Tujuan penelitian ini untuk meningkatkan hasil belajar Hasil Belajar Materi Operasi Hitung Bilangan Dengan Pembelajaran Kooperatif Tipe Make a Match di kelas VI Sekolah Dasar Negeri 12 Kampung Melayu Kecamatan Ampek Nagari Kab. Agam. Penelitian ini adalah PTK (Penelitian Tindakan Kelas) yang terdiri dari II siklus 2 kali pertemuan dengan empat komponen yaitu perencanaan, tindakan, pengamatan dan refleksi. Hasil penelitian menunjukan siklus I bahwa rata-rata hasil belajar siswa diperoleh yaitu 66,19. Sedangkan pada siklus II rata-rata hasil belajar siswa diperoleh 80, terlihat bahwa hasil belajar siswa meningkat dari siklus I ke siklus II. Dengan demikian terungkap bahwa penggunaan komponen-komponen rancangan pembelajaran Kooperatif Tipe Make a Match dapat meningkatkan hasil belajar metematika pada siswa kelas VI SD Negeri 12 Kampung Melayu Kecamatan Ampek Nagari Kab. Agam.
\end{abstract}

\section{Abstract}

The background of the research is the fact that the learning in the Elementary School is often dominated by the teacher as a source of information. Based on the researcher observation, it is found that there is low learning outcome of the students. The researcher used components of cooperative learning design of make a match type. The purpose of the research is to improve the learning outcome of numbers counting operation material through a make a match type cooperative learning at Class IV 
students of Elementary School 12 Kampung Melayu Kecamatan Ampek Nagari Agam Regency. The type of the research is Classroom Action Research (CAR). It used a qualitative and quantitative approach. It was conducted two cycles and 2 meetings with four components, i.e. planning, implementing, observing, and reflecting. Source of data was the learning implementing process with components of cooperative learning design of make a match type at Class IV students of Elementary School 12 Kampung Melayu Kecamatan Ampek Nagari Agam Regency. The subject of the research was class VI Students, i.e. 21 students. The research shows that the average score in the first cycle is 66, 19. Meanwhile, the average score is 80 . It can be seen that there is an improvement from first to second cycle. It can be concluded that using the components of cooperative learning design of make a match type can increase the mathematic learning outcome to the Class IV students of Elementary School 12 Kampung Melayu Kecamatan Ampek Nagari Agam Regency.

\section{PENDAHULUAN}

Matematika diberikan kepada siswa mulai dari sekolah dasar sampai perguruan tinggi. Matematika diajarkan dari sekolah dasar dengan alasan memberi bekal kepada siswa tentang kemampuan berpkir logis, analitis, sistematis, kritis, dan kreatif, serta kemampuan bekerjasama. Kemampuan tersebut diperlukan oleh siswa untuk bertahan hidup pada keadaan yang selalu berubah ini karena perkembangan ilmu pengetahuan dan teknologi (Depdiknas, 2006:1).

Mata pelajaran matematika
merupakan ilmu yang mendasari perkembangan ilmu pengetahuan dan teknologi. Matematika mempunyai peran penting dalam berbagai disiplin dan memajukan daya pikir manusia. Perkembangan pesat dalam ilmu pengetahuan dan teknologi dewasa ini didasari oleh perkembangan matematika di bidang teori bilangan, aljabar, dan analisis. Untuk itu matematika di masa depan diperlukan penguasaan matematika yang kuat dan mantap sejak kecil telah diperkenalkan.Matematika dapat menjadi pelajaran yang menyenangkan bila guru menyajikan pembelajaran dengan merancang pembelajaran dengan efektif mulai dari membuat rencana pelaksanaan pembelajaran dengan baik, menyiapkan penilaian dengan benar, mempersiapkan media pembelajaran yang tepat untuk materi yang akan disampaikan kepada siswa.

Pada mata pelajaran matematika, penulis melakukan penelitian tindakan kelas di kelas VI SD Negeri 12 Kampung Melayu Kecamatan Ampek Nagari. Berdasarkan hasil evaluasi pembelajaran yang penulis lakukan ternyata dari 21 orang siswa hanya 9 orang $(43 \%)$ yang menguasai materi pembelajaran yang diberikan oleh guru yaitu operasi hitung bilangan bulat, sementara 12 orang $(57 \%)$ berada di bawah KKM yang ditetapkan sebesar 70 . 
Berpedoman pada keadaan ini yang menjadi indikasi rendahnya penguasaan siswa terhadap pengetahuan konseptual matematika diamati melalui beberapa indikator sebagai berikut: (a) Rendahnya hasil belajar siswa dengan memberikan beberapa ulangan kepada siswa rata-rata yang dicapai hanya 65, (b) Siswa kurang aktif dalam proses pembelajaran karena tidak ada yang mengacungkan tangan ketika guru memberikan kesempatan bertanya (c) Siswa kurang motivasi dalam proses pembelajaran, (d) Siswa kurang paham bila diberi tugas kelompok dalam melakukan suatu tugas, (e) Siswa tidak serius dalam mengerjakan tugas dalam kelompok, (f) Dalam pembelajaran kurang pengelolaan kelas sehingga banyak siswa yang seperti berolok-olok selama proses pembelajaran berlangsung, (g) Siswa kurang memahami materi kalau diberi tugas kelompok, (h) Siswa tidak ada yang bertanya saat diberi kesempatan bertanya oleh guru, (i) Siswa terlihat diam saja saat proses pembelajaran berlangsung.

Hasil belajar merupakan tolak ukur yang digunakan untuk menentukan tingkat keberhasilan siswa dalam memahami konsep saat proses pembelajaran. Apabila telah terjadi perubahan tingkah laku ke arah yang lebih baik pada diri seseorang, maka seseorang dapat dikatakan telah berhasil dalam belajar. Sebagaimana dikemukakan oleh Oemar (2008:2) yaitu "hasil belajar adalah tingkah laku yang timbul, misalnya dari tidak tahu menjadi tahu, timbulnya pertanyaan baru, perubahan dalam tahap kebiasaan keterampilan, kesanggupan menghargai, perkembang- an sifat sosial, emosional, dan pertumbuhan jasmani". Sedangkan menurut Nana (2006:25) hasil belajar adalah: "sesuatu akibat dari proses belajar dengan menggunakan alat pengukuran berupa tes yang disusun secara terencana baik tes tertulis, tes lisan maupun perbuatan". Sementara itu, Arikunto (1990:133) mengatakan bahwa hasil belajar adalah "hasil akhir setelah mengalami proses belajar, perubahan itu tampak dalam perbuatan yang dapat diamati,dan dapat diukur". Berdasarkan beberapa pendapat di atas hasil belajar pada dasarnya adalah suatu kemampuan yang berupa keterampilan dan prilaku baru sebagai akibat latihan atau pengalaman. Hasil belajar siswa juga dapat dilihat dari kemampuan siswa dalam mengingat pelajaran yang telah disampaikan oleh guru selama proses pembelajaran dan bagaimana siswa tersebut dapat menerapkannya dalam kehidupan.

Pengembangan pembelajaran kooperatif dalam proses belajar mengajar menurut Nur Asma (2008:3) bertujuan untuk: 1) Pencapaian hasil belajar, model ini telah menunjukkan bahwa model struktur penghargaan kooperative telah meningkatkan penilaian siswa pada belajar akademik dan perubahan norma yang berhubungan dengan hasil belajar. 2) Penerimaan terhadap perbedaan individu, pembelajaran kooperatif memberi peluang kepada siswa yang berbeda latar belakang dan kondisi untuk bekerja saling bergantung satu sama lain atas tugas-tugas bersama, dan melalui penggunaan struktur penghargaan kooperatif, serta belajar untuk 
menghargai satu sama lain. 3) Pengembangan keterampilan sosial, pembelajaran kooperatif mengajarkan kepada siswa keterampilan kerja sama dan kolaborasi.

Prinsip dasar pembelajaran kooperatif menurut Nur Asma (2008:5) ada lima prinsip yang dianut, yaitu:

\section{a. Belajar Siswa Aktif}

Proses pembelajaran dengan model pembelajaran kooperatif berpusat pada siswa, aktivitas belajar lebih dominan dilakukan siswa, pengetahuan yang dibangun dan ditemukan adalah dengan belajar bersma-sama anggota kelompok sampai masing-masing siswa memahami materi pembelajaran dan mengakhiri dengan membuat laporan kelompok dan individual.

b. Belajar Kerjasama

Proses pembelajaran dilalui dengan kerjasama dalam kelompok untuk membangun pengetahuan yang tengah dipelajari. Diyakini pengetahuan yang diperoleh melalui penemuan-penemuan dari hasil kerjasama akan lebih bernilai permanen dalam pemahaman masingmasing.

c. Pembelajaran Partisipatorik

Model pembelajaran ini siswa belajar dengan dengan melakukan sesuatu (learning by doing) secara bersama-sama menemukan dan membangun pengetahuan yang menjadi tujuan pembelajaran.

\section{d. Reactive Teaching}

Untuk menerapkan model ini guru perlu menciptakan strategi yang tepat agar seluruh siswa mempunyai motivasi belajar yang tinggi. Ciri-ciri guru yang reaktif: 1) menjadikan siswa sebagai pusat kegiatan belajar, 2) pembelajaran dari guru dimulai dari hal-hal yang diketahui dan dipahami siswa, 3) selalu menciptakan suasana belajar yang menarik bagi siswa-siswanya, 4) mengetahui hal-hal yang membuat siswa menjadi bosan dan segera menanggulanginya.

e. Pembelajaran yang Menyenangkan

Suasana belajar yang menyenangkan harus dimulai dari sikap dan prilaku guru di luar dan di dalam kelas. Langkahlangkah model pembelajaran kooperatif tidak akan berjalan efektif jika suasana belajar yang ada tidak menyenangkan.

Pembelajaran yang bersifat kooperatif ini sebenarnya telah lama digunakan dalam pendidikan di negara kita. Pembelajaran kooperatif diartikan sebagai pembelajaran yang menggunakan kelompok kecil yang dapat menumbuhkan kerja sama secara maksimal dan masing-masing siswa belajar satu dengan lainnya. Dalam kelompok pembelajaran kooperatif, para siswa mempunyai dua tanggung jawab yaitu belajar konten yang telah dirancang dan menjadikan semua anggota kelompok bekerja sama. Memperhatikan beberapa hal yang telah dikemukan, maka pada hakikatnya cooperative learning itu merupakan sistem pembelajaran yang memegang teguh filosofi maju bersama dalam suasana kompetitif untuk memberikan yang terbaik bagi kelompok. Oleh karena itu, pada abad ke- 21, format cooperative learning sangat diperlukan, terutama untuk menunjang pilar to live together. Pilar to live together sebagai landasan pendidikan dari ketiga pilar sebelumnya dengan pengembangan pemahaman dan apresiasi tentang orang lain dan 
sejarahnya, tradisi dan nilai-nilai spritual, dan mendasarkan pada semangat baru untuk mengapresiasikan dan mengamalkan kondisi saling ketergantungan, keanekaragaman, saling memahami dan memecahkan konflik dengan cara damai.Dengan adanya model pembelajaran kooperatif ini maka membantu sekali dalam meningkatkan aktivitas siswa dalam pembelajaran karena model pembelajaran kooperatif mengharuskan siswa untuk bekerjasama dengan teman dan gurunya. Bentuk dari model pembelajaran kooperatif ini pada umumnya berupa kerja kelompok seperti diskusi kelompok, melaksanakan percobaan, pengamatan. Bila aktivitas belajar siswa telah meningkat maka akan memudahkan guru dalam mengembangkan materi pelajaran sehingga hasil belajar yang diharapkan dapat tercapai dengan baik dan lebih memuaskan sekali. Siswa memilki kemampuan belajar yang dapat dibawanya selama hidupnya dengan istilah belajar sepanjang hayat.

Menurut Lorna Curran (1994) pembelajaran kooperatif tipe make a match (mencari pasangan) merupakan satu model pembelajaran kooperatif yang paling sederhana dan baik untuk pembelajaran yang baru mengenal tentang pembelajaran kooperatif.

Kegiatan pembelajaran make match terdiri dari delapan tahap menurut Lorna Curran (1994) yaitu “1) guru menyiapkan beberapa kartu yang berisi beberapa konsep atau topik yang cocok untuk sesi review, sebaiknya satu bagian kartu soal dan bagian lainnya kartu jawaban, 2) setiap siswa mendapat satu buah kartu, 3) tiap siswa memikirkan jawaban atau soal dari kartu yang dipegang, 4) setiap siswa mencari pasangan yang mempunyai kartu cocok dengan kartunya (soal jawaban), 5) Setiap siswa yang dapat mencocokkan kartunya sebelum batas waktu diberi poin, 6) setelah satu babak kartu dikocok lagi agar tiap siswa mendapat kartu yang berbeda dari sebelumnya, 7) kegiatan dilakukan secara berkelanjutan, 8) kesimpulan disertai penutup.

Setiap anggota kelompok harus memberikan skor yang terbaik kepada kelompoknya dengan menunjukkan peningkatan penampilan dibandingkan sebelumnya. Dengan mencari pasangan ini membuat siswa aktif untuk mencari pasangan dan aktif berpikir untuk menemukan jawaban dari soal yang dicarinya. Sehingga siswa menjadi akrab dengan sesama temannya dan pembelajaran menjadi efektif.

\section{METODE PENELITIAN}

Jenis yang dilakukan adalah penelitian tindakan kelas dengan menggunakan pendekatan kualitatif. Pendekatan ini berkenaan dengan perbaikan atau peningkatan hasil belajar siswa dalam proses pembelajaran pada suatu kelas. Pendekatan kualitatif digunakan karena suatu prosedur penelitian yang menghasilkan data deskriptif berupa kata-kata tertulis atau lisan serta perilaku yang diamati dari orang-orang atau sumber informasi (Bogdar dan Taylor, 1992:21). Jenis penelitian yang dilakukan merupakan penelitian tindakan kelas (action research) di bidang pendidikan, dalam penelitian tindakan kelas diadakan perlakuan tertentu yang didasarkan pada 
masalah-masalah aktual yang ditemukan di lapangan. Penelitian ini berkenaan dengan perbaikan atau meningkatkan hasil belajar siswa dalam proses pembelajaran matematika pada suatu kelas.

Alur penelitian ini akan dirancang atas 2 siklus dan masing - masing siklus terdiri dari perencanaan, tindakan (pelaksanaan), dan refleksi. Kemmisb (dalam Kunandar, 2008:43) mengungkapkan bahwa "model siklus ini mempunyai 4 komponen, yaitu perencanaan, tindakan, pengamatan, dan refleksi”.

Sebelum melaksanakan penelitian kegiatan ini dimulai dengan menentukan jadwal penelitian. Penelitian meminta persetujuan kepala sekolah dan guru kelas untuk melakukan penelitian. Setelah itu peneliti berunding dengan guru kelas mengenai waktu pelaksanaan penelitian tersebut. Setelah didapat waktu dilaksanakannya penelitian langkah selanjutnya yaitu mengkaji Kurikulum Tingkat Satuan Pendidikan. Di dalam kurikulum itu terdapat standar kempetensi yang merupakan tujuan umum dari pembelajaran yang harus dicapai siswa. Kompetensi dasar adalah penjabaran dari standar kompetensi.

Pengamatan terhadap tindakan pembelajaran untuk meningkatkan hasil belajar matematika dilakukan bersaman dengan pelaksanaan tindakan. hal ini dilakukan secara intensif, objektif, dan sistematis. Pengamatan dilakukan oleh observer pada waktu guru praktisi melaksanakan tindakan pembelajaran Kooperatif Tipe Make a Match. Kegiatan observasi dilakukan oleh peneliti dan guru untuk mengamati aktivitas siswa selama proses belajar mengajar, aktivitas siswa tersebut dicatat pada lembaran observasi oleh observer. Kegiatan observer untuk masing-masing siklus dilakukan sebanyak satu kali pertemuan. Pada kegiatan ini peneliti dan guru mengamati lembaran observasi yang telah dilakukan. Serta melakukan diskusi tentang kelebihan dan kekurangan yang terdapat pada pembelajaran yang telah dilakukan. Apabila terdapat kekurangan maka dilakukan perbaikan terhadap kegiatan pembelajaran. Selain itu guru dan peneliti mengulas dan menjelaskan perbedaan rencana dan pelaksanaan tindakan yang telah dilakukan. Lalu melakukan interversi, pemaknaan dan penyimpulan data yang diperoleh. Hasil refleksi refleksi ini bermanfaat sebagai masukan pada tindakan selanjutnya. Selain itu, hasil kegiatan refleksi setiap tindakan digunakan untuk menyusun simpulan terhadap hasil tindakan I dan II.

Teknik yang dilakukan untuk pengumpulan data adalah teknik pencatatan lapangan, observasi dan evaluasi (tes). Data yang diperoleh dalam penelitian dianalisis dengan menggunakan model analisis data kualitatif yang ditawarkan oleh Miles dan Huberman (1992:18) yakni analisis data dimulai dengan menelaah sejak mulai pengumpulan data sampai seluruh data terkumpul. Data tersebut direduksi berdasarkan masalah yang diteliti, didikuti penyajian data dan terakhir penyimpulan atau verifikasi. Analisis data dilakukan terhadap data yang telah direduksi baik data perencanaan, pelaksanaan, maupun data evaluasi. 
Analisis data dilakukan dengan cara terpisah-pisah. Hal ini dimaksudkan agar dapat ditemukan berbagai informasi yang spesifik dan terfokus pada berbagai informasi yang mendukung pembelajaran dan menghambat pembelajaran. Dengan demikian, pengembangan dan perbaikan atas berbagai kekurangan dapat dilakukan tepat pada aspek yang bersangkutan.

Analisis data kuantitatif yaitu analisis terhadap hasil belajar sesuatu dengan mengunakan persentase yang dikemukakan oleh Dhydiet dalam Rizka (2008) dengan rumus sebagai berikut:

$\mathrm{P}=\frac{F}{N} \mathrm{X} 100 \%$

Keterangan:

$\mathrm{P} \quad=$ Persentase

$\mathrm{F} \quad=$ Frekuensi

$\mathrm{N}$ = Jumlah responden

Kriteria keberhasilan setiap tindakan adalah $70 \%$. Nilai ketuntasan materi siswa.

\section{HASIL DAN PEMBAHASAN}

Siswa menyimpulkan pelajaran dengan tanya jawab, siswa lalu diberi soal post tes dan mencatat pekerjaan rumah yang diberikan oleh guru. mengamati kegiatan guru dan siswa sewaktu proses pembelajaran di kelas dan mencatat hasil pengamatan dengan menggunakan instrumen penelitian berupa lembaran hasil belajar siswa, lembaran keberhasilan guru dalam pembelajaran.

Pada kesempatan ini segala macam temuan dan hasil pengamatan dibahas mulai dari perencanaan, pelaksanaan, dan hasil yang diperoleh siswa. Selama pelaksanaan tindakan dianalisis dan didiskusikan dengan pengamat, diperoleh hal-hal sebagai berikut:

1. Materi masih terlalu luas penggunaan waktu kurang efisien

2. Kurang memberi motivasi kepada siswa saat siswa mengadakan kerja kelompok.

3. Belum seluruh siswa yang aktif dalam pembelajaran karena masih ada yang diam dan bermain saat kerja kelompok dilakukan.

Guru mengadakan apersepsi yang tepat untuk melihat sejauh mana pengetahuan siswa terhadap materi lalu yang telah diberikan. Setelah siswa menjawab pertanyaan guru barulah guru menyampaikan tujuan pembelajaran dan berusaha memusatkan perhatian siswa. Pada tahap ini siswa memperhatikan guru menyajikan operasi hitung bilangan. Kegiatan awal memakan waktu 5 menit. Kegiatan Inti Waktu yang digunakan dalam kegiatan inti selama 50 menit. Langkah kegiatan guru dan siswa dalam siklus ini berupa: Guru menyiapkan beberapa kartu yang berisi beberapa konsep atau topik pecahan biasa, pecahan desimal, dan persen yang cocok untuk sesi review, siswa lalu mendapat satu buah kartu, guru membacakan soal dan siswa mencari pasangan yang mempunyai kartu yang sama. Siswa yang dapat mencocokkan kartu mendapatkan poin. Setelah satu babak kartu dikocok lagi dan siswa mengambil kartu lagi dan diteruskan sesuai dengan tahap sebelumnya. 


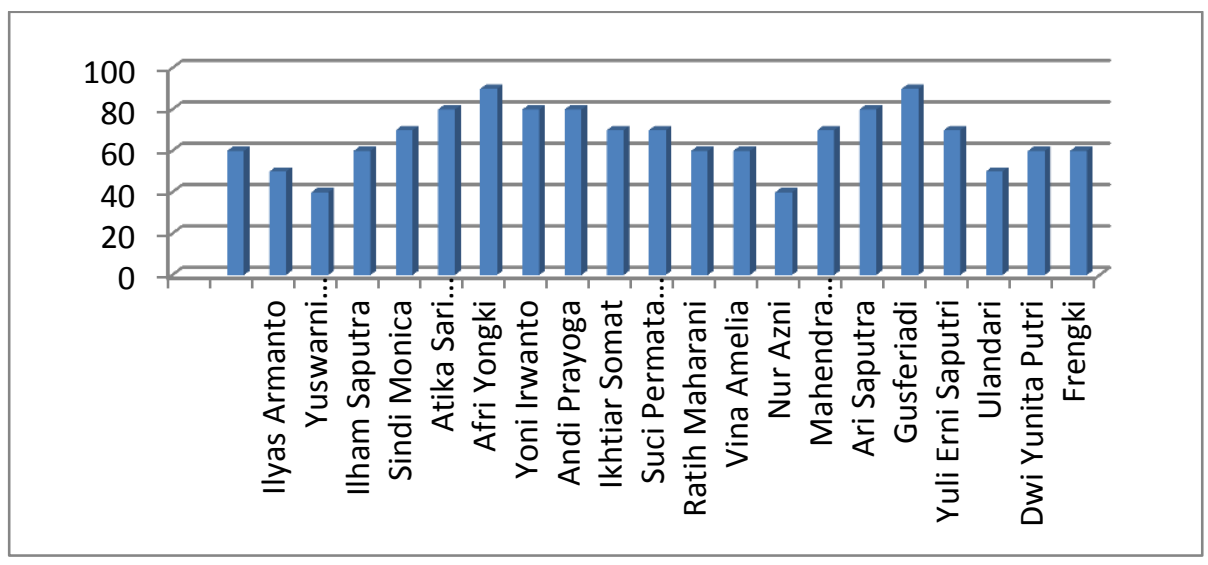

Gambar 1. Hasil belajar Matematika Kelas VI

Siswa menyimpulkan pelajaran dengan tanya jawab, siswa lalu diberi soal postes dan mencatat pekerjaan rumah yang diberikan oleh guru. Kegiatan Akhir Siswa menyimpulkan pelajaran dengan tanya jawab, siswa lalu diberi soal postes dan mencatat pekerjaan rumah yang diberikan oleh guru.

Pada tahap penyajian materi guru telah menyajikan dimulai dengan menjelaskan tujuan, memberikan motivasi untuk berkooperatif, menggali pengetahuan prasyarat dan sebagainya. Dalam penyajian materi guru menggunakan metode ceramah, tanya jawab, diskusi, penugasan, dan sebagainya, disesuaikan dengan isi bahan ajar dan kemampuan pembelajar. Guru telah menyadari akan tugasnya sebagai pengajar maupun sebagai pengelola kelas, dalam hal ini guru telah mampu mengelola, merancang rencana pembelajaran secara sistematis dan lebih terurai. Guru sudah mampu meneliti kesulitan belajar siswanya dan memilih kegiatan yang belajar yang tepat dalam memberikan perbaikan pada siswa secara bertahap.
Guru telah menggunakan metode yang bervariasi dalam proses belajar mengajar sehingga pembelajaran menjadi menarik tidak monoton seperti pembelajaran sebelumnya. Pada kegiatan belajar kelompok siswa masih banyak yang kelihatan tidak tertarik untuk belajar kelompok terlihat masih ada siswa yang diam saat temannya telah memimpin diskusi kelompok. 1) guru menyiapkan beberapa kartu yang berisi beberapa konsep atau topik yang cocok untuk sesi review, sebaiknya satu bagian kartu soal dan bagian lainnya kartu jawaban, 2) setiap siswa mendapat satu buah kartu, 3) tiap siswa memikirkan jawaban atau soal dari kartu yang dipegang, 4) setiap siswa mencari pasangan yang mempunyai kartu cocok dengan kartunya (soal jawaban), 5) Setiap siswa yang dapat mencocokkan kartunya sebelum batas waktu diberi poin, 6) setelah satu babak kartu dikocok lagi agar tiap siswa mendapat kartu yang berbeda dari sebelumnya, 7) kegiatan dilakukan secara berkelanjutan, 8) kesimpulan disertai penutup.

Siswa masih belum aktif dalam kegiatan kelompoknya. Dari 
pemeriksaan hasil tes terlihat nilai ratarata kelas siswa masih rendah yaitu 66,19 dibawah kriteria ketuntasan minimal. Berdasarkan hasil pengamatan dan diskusi dengan observer maka direncanakan untuk melakukan siklus II.

Tahap penyajian materi dilaksanakan guru dalam 5 menit saja karena waktu yang tersedia sedikit, sehingga guru hanya menyajikan sedikit materi yang penting saja. Siswa terlihat lebih gembira dalam melakukan pembelajaran kooperatif tipe make a match, siswa sangat antusias untuk melakukan pembelajaran sebab siswa akan mencari pasanagn kartu yang dicarinya. Secara individu terlihat siswa asyik mengerjakan sendiri. Tahap pemeriksaan hasil tes terlihat rata-rata kelas telah naik dari 66,19 menjadi 80 tetapi masih ada 2 siswa yang belum tuntas. Dari analisis penelitian siklus II ini maka diambil kesimpulan perbaikan dihentikan sampai disini.

\section{PENUTUP}

Berdasarkan kesimpulan yang telah diperoleh dalam penelitian ini, maka dapat disimpulkan bahwa pembelajaran Matematika dengan model pembelajaran kooperatif tipe Make a Match ini dapat meningkatkan hasil belajar siswa. Pelajaran dengan menggunakan model pembelajaran kooperatif tipe Make a Match memiliki kebaikan dan keterbatasan yang disebabkan siswa kurang memahami konsep yang baru didapat. Pembelajaran Matematika harus sesuai dengan konsep yang telah ada sehingga guru dalam mengajar haruslah menanamkan konsep yang benar pada siswa. Agar pembelajaran lebih bermakna guru haruslah memilih media yang tepat untuk pembelajaran seperti lingkungan yang langsung dijadikan sebagai sumber belajar yang digunakan oleh peneliti.

\section{UCAPAN TERIMA KASIH}

Penelitian ini terlaksana karena adanya dukungan dari pihak SD Negeri 12 Kampung Melayu Kecamatan Ampek Nagari dengan UPT Dinas Pendidikan Kecamatan Lubuk Basung yang telah memfasilitasi dan membantu untuk kelancaran penyelesaikan penelitian ini.

\section{DAFTAR PUSTAKA}

Andayani, dkk, 2009, Pemantapan Kemampuan Profesional, Jakarta : Universitas Terbuka.

Badan Standar Nasional Pendidikan. 2006. Kurikulum Tingkat Satuan Pendidikan. Jakarta: Depdiknas

Depdiknas. 2005. 35 Model Pembelajaran yang Efektif. Jakarta: Depdiknas

Khafid M , 2002, Matematika Untuk Kelas VI, Jakarta : Erlangga

Mikarsa lestari hera, dkk, 2004, Pendidikan Anak di SD, Jakarta : Universitas Terbuka

Nur, Asma. 2006. Model Pembelajaran Kooperatif. Jakarta: Depertemen Pendidikan Nasional

Nurhadi dan Agus Gerrad Senduk. 2003. Pembelajaran Kontekstual

(Contextual Teaching and Learning/ CTL) dan Penerapannya dalan KBK. Malang: Universitas Negeri Malang 
Nur Saadah Yunita. 2010. Pemakaian Model Make A Match di sertai Picture And Picture dalam TIK (http://nursaadahyunita.files.wordp ress.com diakses tanggal 20 Maret 2011)

Subana M dan Sunarti, Strategi Belajar Mengajar, Bandung : Pustaka Setia

Suciati, dkk. 2004. Belajar dan Pembelajaran, Jakarta: Universitas Terbuka
Syamsudin, Abim, dan Nandang Budiman, 2002, Profesi Keguruan 2, Jakarta, Universitas Terbuka.

Suryosubroto, B, 2002, Proses Belajar Mengajar, Jakarta: Rineka Cipta Pendidikan Nasional

Wardani, dkk, 2003, Penelitian Tindakan Kelas, Jakarta: Universitas Terbuka

Wina, Sanjaya. 2005, Pembelajaran dalam Implementasi KBK, Jakarta: Kencana. 